\section{The Influence of Drip Irrigation or Subirrigation on Zucchini Squash Grown in Closed-loop Substrate Culture with High and Low Nutrient Solution Concentrations}

\author{
Youssef Rouphael \\ Dipartimento di Geologia e Ingegneria Meccanica, Naturalistica e Idraulica \\ per il Territorio, Università della Tuscia, 01100 Viterbo, Italy; and the \\ Department of Crop Production, Faculty of Agricultural and Veterinary \\ Sciences Lebanese University, Dekwaneh-Al Maten, Lebanon \\ Giuseppe Colla ${ }^{\mathbf{1}}$ \\ Dipartimento di Geologia e Ingegneria Meccanica, Naturalistica e Idraulica \\ per il Territorio, Università della Tuscia, 01100 Viterbo, Italy
}

Additional index words. Cucurbita pepo L., electrical conductivity, irrigation system, mineral composition, soilless

\begin{abstract}
Zucchini plants (Cucurbita pepo L. cultivar Afrodite) were grown during a summer-fall season in closed-soilless systems using a mixture peat-pumice to evaluate the effects of irrigation system (drip irrigation and subirrigation) and nutrient solution concentration (half $=1 \mathrm{dS} \cdot \mathrm{m}^{-1}$ and full $=2 \mathrm{dS} \cdot \mathrm{m}^{-1}$ ) in terms of substrate electrical conductivity $\left(E_{\mathrm{s}}\right)$ using the dilution 1:1.5 media:water method, growth, yield, leaf mineral composition, fruit quality, and mineral solution composition. At the end of the cultural cycle, the highest $\mathrm{EC}_{\mathrm{s}}$ at the upper $(0$ to $7.5 \mathrm{~cm})$ and lower $(7.5$ to $15.0 \mathrm{~cm})$ layers were recorded with subirrigation using a full nutrient solution concentration. The highest plant growth, yield, and leaf macroelements concentration (nitrogen, phosphorus, and potassium) were recorded in both irrigation systems using a full-strength solution, followed by drip irrigation, and finally by subirrigation treatment using a halfstrength nutrient solution. Fruit yield, fruit mineral composition (phosphorus, potassium, calcium, and magnesium), and leaf macroelements concentration (nitrogen, phosphorus, potassium, and magnesium) were substantially reduced when the concentrations of macronutrients in the feed solution were lowered to $50 \%$ of control. Using half-nutrient solution concentration, the marketable yield reduction was more pronounced with subirrigation $(58 \%)$ than with drip irrigation $(42 \%)$. The variation of the macronutrient and $\mathrm{EC}$ in the solution during the growing cycle was less pronounced in the subirrigation than with the drip irrigation system, which represents an important aspect for the simplification of the closed-loop management of the nutrient solution.
\end{abstract}

The greenhouse industry applies more fertilizer per unit area than any other agricultural system (Molitor, 1990). Minimizing fertilizer and water requirements for greenhouse production has become increasingly important to growers, because many are faced with higher water and fertilizer costs, decreasing availability of quality water, and government regulations to protect surface and groundwater (Uva et al., 2001; Van Os, 1999). The only possibility, both to optimize fertilization and keep environmental contamination under control, is to adopt cultivation systems that collect and reuse the extra irrigation water (closed-soilless systems).

Received for publication 1 Oct. 2008. Accepted for publication 21 Nov. 2008.

${ }^{1}$ To whom reprint requests should be addressed; e-mail giucolla@unitus.it.
Recirculating subirrigation culture has lower nutrient and water requirements, delivers nutrients in a uniform manner, avoids foliar wetting (disease prevention), offers greater flexibility in pot sizing and spacing, and reduces the discharge of nutrients to surrounding ecosystems (Biernbaum, 1990, 1992; Santamaria et al., 2003). These benefits lead to savings in labor, material input, and product losses (Purvis et al., 2000; Uva et al., 1998). Besides, the subirrigation system can simplify the closed-loop management of the nutrient solution. In fact, in subirrigation systems, elements that are not absorbed by the plant accumulate in the upper part of the substrate where roots are less present rather than accumulating in the nutrient solution as it would do in a drip irrigation system (Incrocci et al., 2006; Rouphael and Colla, 2005, Rouphael et al., 2008). However, salt accumulation at the substrate surface is a major drawback of this cultural technique (Argo and Biernbaum, 1996; Morvant et al., 1997; Rouphael and Colla, 2005; Rouphael et al., 2006). This problem can be exacerbated by high fertilizer application rates. Commercial greenhouse growers typically use high nutrient concentrations in an attempt to maximize crop yield. This practice does not present an economically optimized production strategy, because excessive nutrients do not necessarily translate into higher yields. Several papers have documented the advantages of using a low nutrient solution concentration for greenhouse cultivation of pot ornamentals. For instance, Rouphael et al. (2008) showed that macronutrient concentrations, commonly used by commercial greenhouse geranium growers, can be reduced by $50 \%$ during the winter cropping cycle without having any adverse effect on shoot dry weight, growth, and quality index. Similarly, for potted gerbera production, Zheng et al. (2004) demonstrated that current nutrient application rates could be reduced by at least $50 \%$ without any detrimental effect on plant growth and quality. However, there is a lack of information about the application of low nutrient concentrations to vegetable production, in particular zucchini squash, widely grown in unheated greenhouses in the Mediterranean region, especially in Italy, where 17,026 ha are annually cultivated (ISTAT, 2007).

Starting from these considerations, the objective of this study was to determine the effects of the nutrient solution concentration (full or half strength) and irrigation system (drip irrigation or subirrigation) during a summer-fall growing season on substrate electrical conductivity, growth, yield, fruit quality, mineral contents of leaves and fruits, and nutrient solution composition of hydroponically grown zucchini. These results may be applied in management decisions of the grower for improving crop performance.

\section{Materials and Methods}

Location, plant material, and growth conditions. The experiment was conducted in summer-fall growing season in a $300-\mathrm{m}^{2}$ 
polyethylene greenhouse situated on the Experimental Farm of Tuscia University, Central Italy (lat. $42^{\circ} 25^{\prime} \mathrm{N}$, long. $12^{\circ} 08^{\prime} \mathrm{E}$ ). Plants were grown under natural light conditions; ventilation was provided automatically when the air temperature exceeded 25 ${ }^{\circ} \mathrm{C}$. The zucchini squash (Cucurbita pepo L.) cultivar Afrodite (Syngenta, Basel, Switzerland) was selected as one of the most representative dark green varieties cultivated in Italy as a result of its high crop performance, fruit quality, precocity, tolerance to fungi (Erisyphe chicoracearum D.C.) and virus (zucchini yellow mosaic virus, watermelon mosaic virus, cucumber mosaic virus), and the high demand of this fruit typology on national and international markets (Antonelli, 2003).

Seeds were germinated in vermiculite on 22 Aug. The seedlings were transplanted $15 \mathrm{~d}$ after sowing (6 Sept.) at the two true-leaf stage into pots (diameter $17 \mathrm{~cm}$, height 19 $\mathrm{cm}$ ) containing $3.4 \mathrm{~L}$ of a mixture peatpumice (pumice have a particle size of 5 to $10 \mathrm{~mm}$ in diameter) in a 1:2 volume ratio. Peat was composed mainly of partially decomposed sphagnum moss species (sphagnum peat) with a degree of decomposition of H-3 according to the Von Post scale (Von Post, 1922). Peat was amended with calcium carbonate to raise the $\mathrm{pH}$ from 3 to 6 . The pots were placed on $26 \mathrm{~cm}$ wide and $6 \mathrm{~m}$ long troughs with $50 \mathrm{~cm}$ between pots and $95 \mathrm{~cm}$ between troughs giving a density of 2.1 plants $/ \mathrm{m}^{-2}$.

Treatments were arranged in a randomized complete block design with four replicates. The treatments were defined by a factorial combination of two nutrient solution concentrations $(50 \%$ or $100 \%$ of a fullstrength nutrient solution) and two irrigation systems (drip and subirrigation). Each experimental unit consisted of one bench containing 10 plants.

Nutrient solution management. The quality of the irrigation water was typical of the area. The concentrations of ions expressed as $\mathrm{mg} \cdot \mathrm{L}^{-1}$ were: chlorine $(\mathrm{Cl} ; 39.0)$, calcium $(\mathrm{Ca}$; 52.1), magnesium ( $\mathrm{Mg} ; 14.6)$, sodium $(\mathrm{Na}$; 29.8), potassium ( $\mathrm{K} ; 27.3)$, and $\mathrm{HCO}_{3}(238.0)$. The full-strength nutrient solution used in this experiment consisted of the following macroand micronutrients $\left(\mathrm{mg} \cdot \mathrm{L}^{-1}\right): \mathrm{NO}_{3}-\mathrm{N}(173.7)$, sulfur (25.6), phosphorus (P; 37.1), K (195.5), Ca (136.2), Mg (55.9), Na (29.8), Cl (39.0), iron (1.11), manganese (0.49), copper (0.09), zinc (0.19), boron (0.21), and molybdenum (0.02). The half-strength nutrient solution had $50 \%$ of the macronutrient and the same micronutrient concentrations of the full-strength nutrient solution.

In all tanks, electrical conductivity (EC) was $2.0 \mathrm{dS} \cdot \mathrm{m}^{-1}$ and $1.0 \mathrm{dS} \cdot \mathrm{m}^{-1}$ for the fulland half-strength nutrient solutions, respectively. Moreover, when the EC values exceeded the threshold of 2.5 and $1.25 \mathrm{dS} \cdot \mathrm{m}^{-1}$ for the full- and half-strength nutrient solutions, respectively, water was added to the nutrient solutions to restore the EC to the original target values. In all treatments, the $\mathrm{pH}$ of the solution was maintained between 5.8 and 6.2 by adding an acid mixture with the same anionic ratio of the nutrient solution using concentrated nitric, phosphoric, and sulfuric acid.

Nutrient solution was pumped from independent tanks (one tank of $100 \mathrm{~L}$ per experimental unit) through a drip and subirrigation system. In the subirrigation system, the nutrient solution was pumped at the elevated end of the benches and allowed to run slowly down the trough past the pots, and the excess was drained back to the tank for later recirculation. In the drip irrigation system, the nutrient solution was pumped from independent tanks and administered through one emitter per plant (flow rate of $2 \mathrm{~L} / \mathrm{h}$ ) and the excess was drained back to the tank for later recirculation. In all treatments (drip irrigation and subirrigation), irrigation scheduling was performed using electronic lowtension tensiometers (LT-Irrometer, Riverside, CA) that control irrigation based on substrate matric potential (Norrie et al., 1994). Tensiometers have been placed at approximately the midpoint of the pots $(\approx 8$ $\mathrm{cm}$ depth). In each treatment, four tensiometers were installed (one for each replicate), and there were located indifferent pots to provide a representative reading of the moisture tension. Tensiometers were connected to an electronic programmer that controlled the beginning $(-5 \mathrm{kPa})$ and the end of irrigation $(-1 \mathrm{kPa})$, which correspond to high and low tension set points for the major part of media (Kiehl et al., 1992). The timing varied from three to seven fertigations per day lasting 20 to $30 \mathrm{~min}$ for the subirrigation and from three to nine fertigations per day of 1 to $3 \mathrm{~min}$ for the drip irrigation. In the drip irrigation, the irrigation volume was increased $30 \%$ above the container capacity to obtain a leachate fraction of $\approx 30 \%$. Typically, leaching fractions of $20 \%$ to $30 \%$ are needed to maintain the EC in the substrate at recommended level (Kempkes and Stanghellini, 2003; Schröder and Lieth, 2002). In subirrigated pots at the end of each irrigation event, the substrate surface appeared to be wetted.

Measurements and analysis. The nutrient composition of the solution obtained from the 16 tanks was analyzed biweekly to establish the variation of the concentrations of macro elements [nitrogen $(\mathrm{N}), \mathrm{P}, \mathrm{K}, \mathrm{Ca}$, and $\mathrm{Mg}$ ] in the nutrient solution using a thermo jarrel ash sequential spectrophotometer (Thermo Optek, Milano, Italy). Fresh weight of marketable fruits, flowers, and fruit number were recorded three times per week on four plants per experimental unit starting on 11 Oct. (36 d after transplanting). Fruits were harvested when they reached marketable size (over 12 $\mathrm{cm}$ ). Fruits that were deformed and less than $12 \mathrm{~cm}$ were considered unmarketable. Fruits were dried in a forced-air oven at $80{ }^{\circ} \mathrm{C}$ for $72 \mathrm{~h}$ and weighed to determine dry matter. Dried samples were ground separately in a Wiley mill (Thomas Scientific, Swedesboro, NJ) to pass through a 20 -mesh screen; then $0.5 \mathrm{~g}$ of the dried fruit tissues was analyzed for the following macronutrients: N, P, K, Ca, and $\mathrm{Mg}$. Nitrogen concentration in the fruit tissue was determined after mineralization with sulfuric acid by the "Regular Kjeldahl method"' (Bremner, 1965), P, K, Ca, and Mg concentrations were determined by dry-ashing at $400{ }^{\circ} \mathrm{C}$ for $24 \mathrm{~h}$, dissolving the ash in $1: 25 \mathrm{HCl}$, and assaying the solution obtained using an inductively coupled plasma emission spectrophotometer (Karla, 1998).

Fifty-seven d after transplanting, eight zucchini fruits per experimental unit were harvested for quality analysis, longitudinal segments were cut from all fruits, fresh weights were taken and the fruit frozen at $-80{ }^{\circ} \mathrm{C}$, freeze-dried, and stored in polyethylene bags at $-20{ }^{\circ} \mathrm{C}$ for the analysis of glucose, fructose, and sucrose, whereas for vitamin $\mathrm{C}$ analysis, sections of sampled fruits were frozen in liquid nitrogen and stored at $-80{ }^{\circ} \mathrm{C}$. The soluble carbohydrates (glucose, fructose, sucrose) contents were determined through an enzyme-linked spectrophotometric assay as described by Jones et al. (1977), including the modification of Antognozzi et al. (1996). The extraction and determination of ascorbate (vitamin C) was performed using the protocol of Kampfenkel et al. (1995).

At final harvest (20 Nov., $76 \mathrm{~d}$ after transplanting), four plants per plot were separated into roots, stems, and leaves, and the plant samples were oven-dried for biomass determination. Dry leaves were ground for $\mathrm{N}, \mathrm{P}, \mathrm{K}, \mathrm{Ca}$, and $\mathrm{Mg}$ determination as previously described for mineral analysis of fruit. Harvest index was calculated as the ratio of dry matter partitioned into the fruit relative to the total plant biomass.

At the midcycle (38 d after transplanting) and after the plants were harvested, the growth medium was sampled for EC measurement. The substrate from four pots from each experimental unit was divided into two equal layers from the surface to the bottom of the pots to determine the EC at the upper ( 0 to $7.5 \mathrm{~cm})$ and lower $(7.5$ to $15.0 \mathrm{~cm})$ layers. The EC of the water extract was obtained using the 1:1.5 (growth medium:deionized water, v/v) method by adding $60 \mathrm{~mL}$ of deionized water to a sample of $40 \mathrm{~mL}$. Growth medium and water were well mixed for $30 \mathrm{~min}$ and then the mixture was filtered and the solids discarded. The EC of filtered extracts was then measured using a conductivity meter (EC 214; Hanna Instruments, Padova, Italy).

Statistical analysis. All data were statistically analyzed by analysis of variance using the SPSS software package (SPSS 10 for Windows, Chicago, IL). Duncan's multiple range test was performed at $P=0.05$ on each of the significant variables measured.

\section{Results}

Growth medium electrical conductivity. At the end of the cultural cycle, the ECs in the upper and lower layers were significantly affected by irrigation system (I), nutrient solution concentration $(\mathrm{C})$, and $\mathrm{I} \times \mathrm{C}$ interaction, whereas the substrate $\mathrm{EC}$ in both layers at the middle of the cultural cycle was highly influenced by the nutrient solution 
concentration but not by irrigation system and $\mathrm{I} \times \mathrm{C}$ interaction (Table 1 ).

At the end of the cultural cycle, the highest ECs in the upper layer were recorded on plants grown in subirrigation using a full nutrient solution concentration, whereas the lowest value was observed on plants grown with drip and subirrigation using the halfstrength nutrient solution concentration.

Yield, biomass production, and partitioning. Total and marketable yield were significantly affected by irrigation system and nutrient solution concentration with significant $\mathrm{I} \times \mathrm{C}$ interaction. Moreover, the fruit number was highly influenced by the irrigation system and nutrient concentration with no significant I $\times$ $\mathrm{C}$ interaction (Table 2). The highest total yield was recorded on plants grown in both drip irrigation and subirrigation system using the full nutrient solution concentration, whereas the lowest value was observed on plants grown with subirrigation using the halfstrength nutrient solution concentration. A similar trend was also observed for marketable yield, in which the lowest marketable yield was recorded on plants grown with drip irrigation and especially with subirrigation using the half nutrient solution concentration with a reduction of $42 \%$ and $58 \%$, respectively, compared with both drip and subirrigation using the full nutrient solution concentration (average $1.75 \mathrm{~kg} / \mathrm{plant}$ ). The lowest yield (total and marketable) recorded in the treatments with half nutrient solution concentration was attributed to a reduction in both the average fruit weight and the number of fruit per plant (Table 2).

The dry weight of leaves, stems, and roots was significantly affected by the irrigation system and the nutrient solution concentration with no $\mathrm{I} \times \mathrm{C}$ interaction, whereas no significant difference among treatments was observed for flowers (average $3.4 \mathrm{~g} / \mathrm{plant}$ ) (Table 3). The dry weight of leaves, stems, and roots was higher in the drip irrigation in comparison with the subirrigation treatment and with the full in comparison with the halfstrength nutrient solution.

Fruit and total dry weight were highly influenced by the irrigation system and the nutrient solution concentration with $\mathrm{I} \times \mathrm{C}$ interaction (Table 3). The fruit dry weight results were fully consistent with those reported for the fresh weight. Moreover, the highest total dry weight was recorded on plants grown in both drip irrigation and subirrigation system using the full nutrient solution concentration, whereas the lowest value was observed on plants grown with subirrigation using the half-strength nutrient solution concentration. No significant difference among treatments was observed for harvest index (average 0.40).

Fruit quality. No significant difference among treatments was observed for fruit dry matter (average 5.5\%) and vitamin $\mathrm{C}$ concentration expressed as milligrams of total ascorbic acid per gram of fresh weight (average 188). Both glucose and fructose

Table 1. Effects of irrigation system and nutrient solution concentration on substrate electrical conductivity $\left(\mathrm{EC}_{\mathrm{s}}\right)$ of the substrate aqueous extract in the middle (38 d after transplanting) and at the end (76 d after transplanting) of the cultural cycle at two layers (upper and lower).

\begin{tabular}{|c|c|c|c|c|c|}
\hline \multirow[b]{3}{*}{ Irrigation system } & \multirow{3}{*}{$\begin{array}{l}\text { Nutrient concn. } \\
\quad\left(\mathrm{dS} \cdot \mathrm{m}^{-1}\right)\end{array}$} & \multicolumn{4}{|c|}{$\mathrm{EC}_{\mathrm{s}}\left(\mathrm{dS} \cdot \mathrm{m}^{-1}\right)$} \\
\hline & & \multicolumn{2}{|c|}{ Midcycle } & \multicolumn{2}{|c|}{ End cycle } \\
\hline & & Upper & Lower & Upper & Lower \\
\hline Drip irrigation & 2.0 & 1.11 & 0.84 & $1.50 \mathrm{~b}^{\mathrm{z}}$ & $0.95 \mathrm{~b}$ \\
\hline \multirow[t]{2}{*}{ Subirrigation } & 2.0 & 1.36 & 1.00 & $2.05 \mathrm{a}$ & $1.22 \mathrm{a}$ \\
\hline & 1.0 & 0.79 & 0.44 & $1.13 \mathrm{c}$ & $0.55 \mathrm{~d}$ \\
\hline \multicolumn{6}{|c|}{ Significance $^{y}$} \\
\hline \multicolumn{2}{|c|}{ Irrigation system (I) } & NS & NS & $* *$ & $*$ \\
\hline
\end{tabular}

${ }^{\mathrm{z}}$ Means within columns separated using Duncan's multiple range test $(P=0.05)$.

${ }^{\mathrm{y}} \mathrm{NS},{ }^{*},{ }^{*}$ Nonsignificant or significant at $P<0.05$ or 0.01 , respectively.

Table 2. Effects of irrigation system and nutrient solution concentration on yield, mean weight and number of total (T), and marketable (M) fruits of zucchini plants.

\begin{tabular}{|c|c|c|c|c|c|c|c|}
\hline \multirow[b]{3}{*}{ Irrigation system } & \multirow{3}{*}{$\begin{array}{l}\text { Nutrient concn. } \\
\qquad\left(\mathrm{dS} \cdot \mathrm{m}^{-1}\right)\end{array}$} & \multirow{2}{*}{\multicolumn{2}{|c|}{ Yield (kg/plant) }} & \multicolumn{4}{|c|}{ Fruit } \\
\hline & & & & \multicolumn{2}{|c|}{ Mean wt (g) } & \multicolumn{2}{|c|}{ Number (no. plant ${ }^{-1}$ ) } \\
\hline & & $\mathrm{T}$ & $\mathrm{M}$ & $\mathrm{T}$ & M & $\mathrm{T}$ & $\mathrm{M}$ \\
\hline \multirow[t]{2}{*}{ Drip irrigation } & 2.0 & $1.92 \mathrm{a}^{\mathrm{z}}$ & $1.81 \mathrm{a}$ & 123.3 & 139.6 & 15.8 & 13.0 \\
\hline & 1.0 & $1.10 \mathrm{~b}$ & $1.01 \mathrm{~b}$ & 103.1 & 126.9 & 10.7 & 8.0 \\
\hline \multirow[t]{2}{*}{ Subirrigation } & 2.0 & $1.76 \mathrm{a}$ & $1.69 \mathrm{a}$ & 125.9 & 139.1 & 14.0 & 12.2 \\
\hline & 1.0 & $0.78 \mathrm{c}$ & $0.74 \mathrm{c}$ & 105.8 & 117.0 & 7.5 & 6.4 \\
\hline \multicolumn{8}{|c|}{ Significance ${ }^{y}$} \\
\hline \multicolumn{2}{|c|}{ Irrigation system (I) } & $* * *$ & $* * *$ & NS & NS & $* *$ & $* *$ \\
\hline \multicolumn{2}{|c|}{ Nutrient concentration (C) } & $* * *$ & $* * *$ & $* *$ & $* *$ & $* * *$ & $* * *$ \\
\hline \multicolumn{2}{|c|}{$\mathrm{I} \times \mathrm{C}$} & $* *$ & * & NS & NS & NS & NS \\
\hline
\end{tabular}

${ }^{\mathrm{z}}$ Means within columns separated using Duncan's multiple range test $(P=0.05)$.

${ }_{\mathrm{N}}^{\mathrm{NS},}{ }^{*}, * *, * * *$ Nonsignificant or significant at $P<0.05,0.01$, or 0.001 , respectively.

Table 3. Effects of irrigation system and nutrient solution concentration on dry biomass production, partitioning, and harvest index (HI) of zucchini plants.

\begin{tabular}{|c|c|c|c|c|c|c|c|c|}
\hline \multirow[b]{2}{*}{ Irrigation system } & \multirow{2}{*}{$\begin{array}{l}\text { Nutrient concn. } \\
\left(\mathrm{dS} \cdot \mathrm{m}^{-1}\right)\end{array}$} & \multicolumn{6}{|c|}{ Dry wt $(\mathrm{g} / \mathrm{plant})$} & \multirow[b]{2}{*}{$\mathrm{HI}$} \\
\hline & & Leaves & Stems & Fruits & Flowers & Roots & Total & \\
\hline Drip irrigation & 1.0 & 59.8 & 15.4 & $62.4 \mathrm{~b}$ & 3.2 & 12.8 & $150.8 \mathrm{~b}$ & 0.42 \\
\hline \multicolumn{9}{|l|}{ Significance $\mathrm{y}^{\mathrm{y}}$} \\
\hline \multicolumn{2}{|c|}{ Irrigation system (I) } & $*$ & $*$ & ** & NS & $*$ & $* *$ & NS \\
\hline \multicolumn{2}{|c|}{ Nutrient concentration $(\mathrm{C})$} & $* * *$ & $* * *$ & $* * *$ & NS & $* *$ & $* * *$ & NS \\
\hline
\end{tabular}

${ }^{\mathrm{z}}$ Means within columns separated using Duncan's multiple range test $(P=0.05)$.

${ }_{\mathrm{NS}},{ }^{*}, * * * * *$ Nonsignificant or significant at $P<0.05,0.01$, or 0.001 , respectively. 
were the predominant sugars, whereas sucrose was present in trace quantities. Neither the irrigation system nor the nutrient solution affected the concentrations of glucose (average $7.1 \mathrm{mg} \cdot \mathrm{g}^{-1}$ fresh wt), fructose (average 6.6 $\mathrm{mg} \cdot \mathrm{g}^{-1}$ fresh wt), and sucrose (average 1.2 $\mathrm{mg} \cdot \mathrm{g}^{-1}$ fresh wt) (data not shown).

Concerning the fruit mineral composition, the $\mathrm{N}$ and $\mathrm{K}$ concentrations were significantly affected by irrigation system and the nutrient solution concentration with no $\mathrm{I} \times \mathrm{C}$ interaction, whereas the $\mathrm{P}, \mathrm{Ca}$, and $\mathrm{Mg}$ concentrations were significantly influenced by nutrient solution concentration but not by the irrigation system and $\mathrm{I} \times \mathrm{C}$ interaction (Table 4). The concentration of $\mathrm{N}$ and $\mathrm{K}$ recorded on fruits grown in drip irrigation was significantly higher by $12 \%$ and $7 \%$, respectively, than those recorded in subirrigation. Finally, the concentration of N, P, K, $\mathrm{Ca}$, and $\mathrm{Mg}$ observed on fruits grown with half-strength nutrient solution was significantly reduced by $28 \%, 14 \%, 19 \%, 26 \%$, and $14 \%$, respectively, than those recorded with full-strength nutrient solution (Table 4).

Leaf mineral composition. The leaf concentration of $\mathrm{N}, \mathrm{P}$, and $\mathrm{K}$ was significantly affected by irrigation system, nutrient solution concentration, and $\mathrm{I} \times \mathrm{C}$ interaction with the highest value recorded on plants grown in drip and subirrigation using a full nutrient solution concentration. The leaf concentration of N, P, and $\mathrm{K}$ was intermediate in plants grown in drip irrigation treatment using halfstrength solution, whereas the lowest value was observed on plants grown with subirrigation using the half-strength nutrient solution concentration (Table 5). The results also indicate that the concentration of $\mathrm{Mg}$ was only affected by nutrient concentration with the highest value recorded in full (average $18.9 \mathrm{mg} \cdot \mathrm{g}^{-1}$ dry wt) than in half (average 13.9 $m g \cdot g^{-1}$ dry wt) -strength nutrient solution plants. Finally, no significant difference among treatments was observed for the $\mathrm{Ca}$ concentration (average $32.9 \mathrm{mg} \cdot \mathrm{g}^{-1}$ dry wt).

Electrical conductivity and composition of the nutrient solution. The EC value of the nutrient solution was always within the range for plants grown in subirrigation, whereas with drip irrigation, the EC exceeded the maximum limit 45 and $55 \mathrm{~d}$ after transplanting for the full- and half-strength nutrient solution, respectively, and therefore water was added to restore the EC to the original target values (data not shown).

The composition of the nutrient solution changed appreciably over the cultural cycle with a reduction of $\mathrm{N}, \mathrm{K}$, and $\mathrm{Mg}$ and an increase of $\mathrm{P}$ and $\mathrm{Ca}$. The percentage variations in the concentrations of macronutrients in the nutrient solutions in comparison with the values of the supply solution were more stable in subirrigation than in the drip irrigation systems in both nutrient solution concentrations (Fig. 1). At the end of the growing cycle, $\mathrm{N}$ decreased with a greater decrease with the drip irrigation system in full- and half-strength solution $(20 \%$ and $73 \%$, respectively) compared with the subirrigation system (12\% and 29\% for full- and half-strength, respectively). Moreover, $\mathrm{K}$ and $\mathrm{Mg}$ concentrations at the end of the growing cycle decreased with higher values observed with the drip system for full $(26 \%$ and $32 \%$, respectively) and half strength $(73 \%$ and $19 \%$, respectively) than with the subirrigation system using full- (13\% and $18 \%$, respectively) and half-strength $(28 \%$ and $4 \%$, respectively) nutrient solution (Fig. 1). Finally, concentrations of $\mathrm{P}$ and $\mathrm{Ca}$ in the nutrient solution at the end of the growing cycle were increased with highest values recorded with the drip irrigation system in both full (13\% and $17 \%$, respectively) and half strength ( $48 \%$ and $11 \%$, respectively) in comparison with the subirrigation system for full- ( $8 \%$ and $9 \%$, respectively) and half(16\% and $3 \%$, respectively) strength nutrient solution.

\section{Discussion}

Accumulation of salts in the growing medium depends on the concentration of salts applied with the nutrient solution, the irrigation system, and the evaporative demand of the environment (Rouphael and Colla, 2005; Rouphael et al., 2008). The subirrigation resulted in higher ECs increasing in the upper and lower layers than with drip irrigation. The highest ECs with subirrigation at the end of the growing cycle can be expected because the unidirectional flow of nutrient solution inside the subirrigated substrate is the result of capillarity force and bulk flow (Reed, 1996; Rouphael and Colla, 2005; Rouphael et al., 2006, 2008). Therefore, a progressive accumulation of the mineral elements not used by the plant occurs in the upper portion of the substrate (Reed, 1996). A similar pattern of salt accumulation with subirrigation systems has been reported in numerous other studies on floricultural and vegetable crops (Cox, 2001; Incrocci et al., 2006; Matysiak and Bielenin, 2005; Rouphael et al., 2006, 2008; Santamaria et al., 2003; Zheng et al., 2004).

Zucchini squash has been reported as a moderately salt-tolerant crop (Graifenberg et al., 1996) with a threshold value of 5.1 $\mathrm{dS} \cdot \mathrm{m}^{-1}$ determined by the saturate past method, which corresponds roughly to ECs obtained with the dilution method $(1: 1.5, \mathrm{v} / \mathrm{v})$ of $\approx 1.7 \mathrm{dS} \cdot \mathrm{m}^{-1}$. In our case, at the end of the growing cycle, in the upper layer, the ECs

Table 4. Effect of irrigation system and nutrient solution concentration on macroelements content in fruits of zucchini plants.

\begin{tabular}{|c|c|c|c|c|c|c|}
\hline \multirow[b]{2}{*}{ Irrigation system } & \multirow{2}{*}{$\begin{array}{l}\text { Nutrient concn. } \\
\quad\left(\mathrm{dS} \cdot \mathrm{m}^{-1}\right)\end{array}$} & \multicolumn{5}{|c|}{ Mineral elements (mg.g ${ }^{-1}$ dry wt) } \\
\hline & & Nitrogen & Phosphorus & Potassium & Calcium & Magnesium \\
\hline Drip irrigation & 1.0 & 29.4 & 7.4 & 35.2 & 2.8 & 8.7 \\
\hline Subirrigation & 1.0 & 24.6 & 7.3 & 31.5 & 2.5 & 8.1 \\
\hline \multicolumn{7}{|l|}{ Significance $^{z}$} \\
\hline \multicolumn{2}{|c|}{ Irrigation system (I) } & * & NS & * & NS & NS \\
\hline \multicolumn{2}{|c|}{ Nutrient concentration (C) } & ** & ** & ** & ** & ** \\
\hline
\end{tabular}

${ }_{\mathrm{NS}},{ }^{*}, * *$ Nonsignificant or significant at $P<0.05$ or 0.01 , respectively.

Table 5. Effect of irrigation system and nutrient solution concentration on leaf macroelements content of zucchini plants.

\begin{tabular}{|c|c|c|c|c|c|c|}
\hline \multirow[b]{2}{*}{ Irrigation system } & \multirow{2}{*}{$\begin{array}{l}\text { Nutrient concn. } \\
\qquad\left(\mathrm{dS} \cdot \mathrm{m}^{-1}\right)\end{array}$} & \multicolumn{5}{|c|}{ Mineral elements (mg. $\mathrm{g}^{-1}$ dry wt) } \\
\hline & & Nitrogen & Phosphorus & Potassium & Calcium & Magnesium \\
\hline Drip irrigation & 1.0 & $26.6 \mathrm{~b}$ & $6.7 \mathrm{~b}$ & $27.9 \mathrm{~b}$ & 30.4 & 15.2 \\
\hline Subirrigation & 2.0 & $32.2 \mathrm{a}$ & $7.8 \mathrm{a}$ & $35.1 \mathrm{a}$ & 35.0 & 19.1 \\
\hline \multicolumn{7}{|l|}{ Significance $^{y}$} \\
\hline \multicolumn{2}{|c|}{ Irrigation system (I) } & ** & ** & ** & NS & NS \\
\hline \multicolumn{2}{|c|}{ Nutrient concentration (C) } & ** & $* * *$ & ** & NS & ** \\
\hline
\end{tabular}

${ }^{2}$ Means within columns separated using Duncan's multiple range test $(P=0.05)$.

${ }_{\mathrm{NS}},{ }^{*}, * *, * * *$ Nonsignificant or significant at $P<0.05,0.01$, or 0.001 , respectively. 


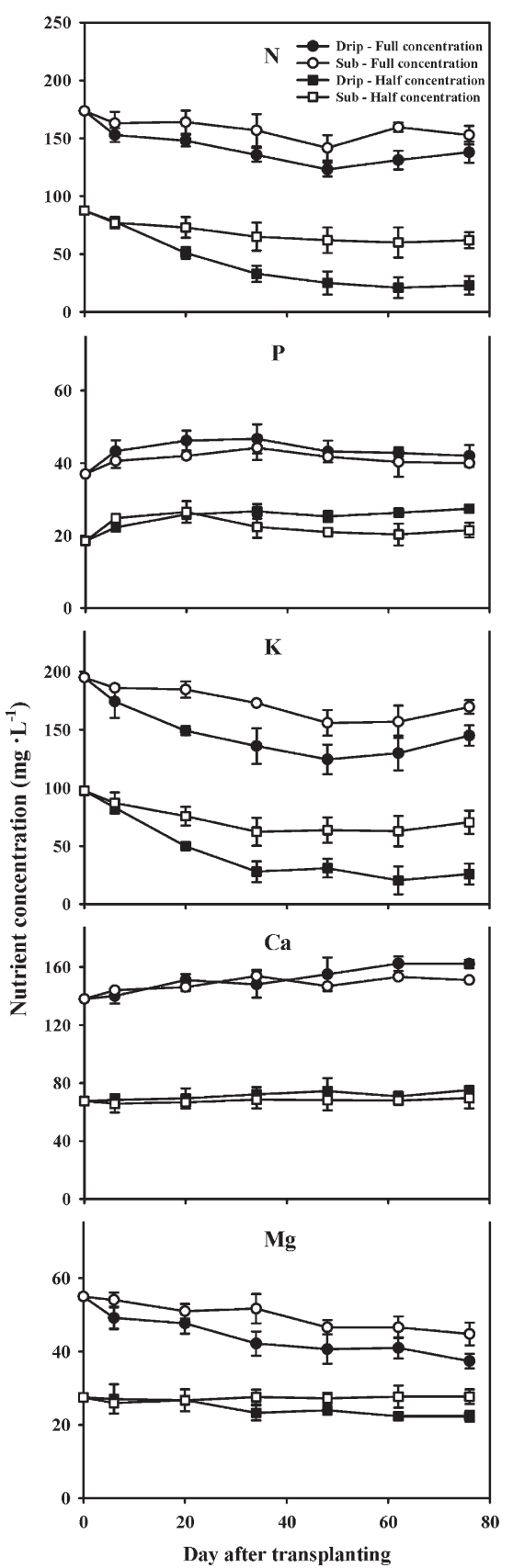

Fig. 1. Nutrient solution concentration of nitrogen $(\mathrm{N})$, phosphorus $(\mathrm{P})$, potassium $(\mathrm{K})$, calcium (Ca), and magnesium (Mg) in drip and subirrigation system using half- and full-strength nutrient solution concentration (76-d monitoring period). Data are the mean of four replicates. Vertical bars indicate \pm SE of the mean; their absence indicates that the size was less than the symbol.

were clearly supraoptimal (greater than 1.7 $\mathrm{dS} \cdot \mathrm{m}^{-1}$ ) with subirrigation using full-strength nutrient solution. Moreover, the ECs of the bottom layers were all below the threshold value. Maintaining favorable ECs in the lower layers of substrate is very important for optimal crop performance as a result of the presence of the greatest proportion of the zucchini root system at this depth. Similarly, Santamaria et al. (2003) found that the growth of tomato was unaffected by the high
ECs in the top layer, and they concluded that salt accumulation in the top layer did not necessarily have detrimental effects on plant growth.

Plant growth, total yield, and marketable yield recorded with subirrigation using fullstrength nutrient solution were not significantly different from those recorded with drip irrigation. The similar crop performance between the two closed systems of solution management could be related to the low substrate $\mathrm{EC}$ recorded in the lower layer at the end of the cultural cycle $\left(0.95\right.$ and $1.20 \mathrm{dS} \cdot \mathrm{m}^{-1}$ for drip and subirrigation, respectively).

Plant growth and marketable fruit yield were substantially reduced by $38 \%$ and $42 \%$, respectively, with drip irrigation and by $55 \%$ and $58 \%$, respectively, with subirrigation when the concentrations of macronutrients in the feed solution were lowered to $50 \%$ of control. Moreover, the reduction of leaf macroelements $(\mathrm{N}, \mathrm{P}$, and $\mathrm{K}$ ) content of zucchini plants in half versus full nutrient solution treatments suggested that the half nutrient solution did not meet the nutrient requirements of zucchini plants. Zucchini squash contrasts sharply with floricultural crops (Rouphael et al., 2008; Zheng et al., 2004) and leafy vegetable crops (Chen et al., 1997; Maruo et al., 2001), in which nutrient concentration can be reduced by at least $50 \%$ without any detrimental effect on plant growth, yield, quality, and macronutrient uptake. This acclimation appears the result of upregulation of nutrient uptake by plant roots as well as increases of root biomass (Siddiqi et al., 1998) and also depends on the plant species because floricultural and leafy vegetable crops are characterized by low nutrient uptake and low growth rate. This was not the case in the current experiment, because a detrimental effect on plant growth, yield, and leaf macroelements concentration was observed when the macronutrients of the solution was reduced to $50 \%$. Explanations for this disagreement could be that zucchini squash differs from floricultural and leafy vegetable crops (which show acclimation of fluxes, as mentioned previously) in that its growth is indeterminate and that it has a relatively large sinks in terms of leaves and fruits. Moreover, with half-strength nutrient solution, the plant growth, yield, and leaf macroelements concentration reduction in comparison with the full strength was more pronounced in plants grown with subirrigation than those grown with drip irrigation. The lower crop performance of subirrigated plants may be related to the low root development, which negatively affected the macronutrient uptake of zucchini plants, leading to a drastic reduction in marketable yield (Rouphael et al., 2006).

In the present study, the two closed systems of solution management did affect the nutritional characteristics of the fruits, because the fruit quality parameters of dripirrigated zucchini such as fruit dry matter, vitamin $\mathrm{C}$, soluble sugars, and concentrations of $\mathrm{P}, \mathrm{Ca}$, and $\mathrm{Mg}$ were similar to that of the plants grown with subirrigation. Moreover, the effect of the nutrient solution concentration on fruit quality was more pronounced. In comparison with half-strength nutrient solution, our results indicate that using a fullstrength solution, higher concentrations of $\mathrm{N}$, $\mathrm{P}, \mathrm{K}, \mathrm{Ca}$, and $\mathrm{Mg}$ were observed, which is interesting from a nutritional point of view because fruits and vegetables usually contribute to $35 \%, 24 \%$, and $11 \%$, respectively, of the total $\mathrm{K}, \mathrm{Mg}$, and $\mathrm{P}$ to the dietary intake of humans (Levander, 1990).

Finally, the nutrient composition and EC of the solution changed over the 76-d trial. The concentration of $\mathrm{N}, \mathrm{K}$, and $\mathrm{Mg}$ at the end of the cultural cycle decreased in comparison with the original solution composition, whereas the opposite trend occurred for $\mathrm{P}$ and $\mathrm{Ca}$. Accumulation of bivalent ion like $\mathrm{Ca}$ and depletion of $\mathrm{N}$ and $\mathrm{K}$ are well-known alterations occurring in the composition of nutrient solutions when recycled (Rouphael et al., 2004; Rouphael and Colla, 2005). Overall, the variation of the macronutrient and $\mathrm{EC}$ in the solution during the growing cycle was less pronounced in subirrigation than with the drip irrigation system, which represents an important aspect for the simplification of the closed-loop management of the nutrient solution.

\section{Conclusions}

The results demonstrate that growing zucchini squash during a summer-fall season, both irrigation systems can be adopted using a standard nutrient solution composition (2.0 $\mathrm{dS} \cdot \mathrm{m}^{-1}$ ), but subirrigation should be preferred during this cropping season as a result of the similar marketable yield and fruit quality of drip irrigation and less variation of EC and macronutrient concentration in the solution during the growing cycle leading to a simplification of the closed-loop management of the nutrient solution. The results also indicate that the effect of the nutrient solution concentration on yield, fruit quality, and leaf macroelement concentration of zucchini was significant and more pronounced than the effect of irrigation system; plant growth and marketable fruit yield were substantially reduced when the concentrations of macronutrients in the feed solution were lowered to $50 \%$ of control. However, using a halfstrength nutrient solution, the drip irrigation system should be preferred because the plant growth, yield, and leaf macroelement concentration reduction in comparison with the full-strength solution was less pronounced than with subirrigation treatment.

\section{Literature Cited}

Antognozzi, E., A. Battistelli, F. Faminani, S. Moscatello, F. Stanica, and A. Tombesi. 1996. Influence of CPPU on carbohydrate accumulation and metabolism in fruit of Actinidia deliciosa (A. Chev). Sci. Hort. 65:37-47.

Antonelli, M. 2003. Zucchino: Le varietà testate nella sperimentazione 2003. Agricoltura 11:76-78.

Argo, R.W. and A.J. Biernbaum. 1996. Availability and persistence of macronutrients from lime 
and perplant nutrient charge fertilizers in peat based root media. J. Amer. Soc. Hort. Sci. 121:453-460.

Biernbaum, J.A. 1990. Are you ready for subirrigation? Amer. Veg. Grower 38:44-45.

Biernbaum, J.A. 1992. Root-zone management of greenhouse container-grown crops to control water and fertilizer use. HortTechnology 2:127-132.

Bremner, J.M. 1965. Total nitrogen, p. 1149-1178. In: Black, C.A., D.D. Evans, I.L. White, L.E. Ensminger, and F.E. Clark (eds.). Methods of soil analysis. Agronomy Monograph 9, Part 2

Chen, X.G., C. Gastaldi, M.Y. Siddiqi, and A.D.M. Glass. 1997. Growth of a lettuce crop at low ambient nutrient concentrations: A strategy designed to limit the potential for eutrophication. J. Plant Nutr. 20:1403-1417.

Cox, D.A. 2001. Growth, nutrient content, and growth medium electrical conductivity of poinsettia irrigated by subirrigation or from overhead. J. Plant Nutr. 24:523-533.

Graifenberg, A., L. Botrini, L. Giustiniani, and M. Lipucci Di Paola. 1996. Yield, growth and element content of zucchini squash grown under saline-sodic conditions. J. Hort. Sci. 71:305-311.

Incrocci, L., F. Malorgio, A. Della Bartola, and A. Pardossi. 2006. The influence of drip irrigation or subirrigation on tomato grown in closedloop substrate culture with saline water. Sci. Hort. 107:365-372.

ISTAT. 2007. < http://www.istat.it/agricoltura/ datiagri/coltivazioni/ital2007.htm $>$. Rome, Italy

Jones, M.G.K., W.H. Outlaw, and O.H. Lowry. 1977. Enzymatic assay of $10^{-7}$ to $10^{-14}$ moles of sucrose in plant tissues. J. Plant Physiol. 64:379-383.

Kampfenkel, K., M. Van Montagu, and D. Inzé. 1995. Extraction and determination of ascorbate and dehydroascorbate from plant tissue. Anal. Bio. 225:165-167.

Karla, Y.P. 1998. Handbook of reference methods for plant analysis. CRC Press Inc., Boca Raton, FL. p. 165-170.

Kempkes, F. and C. Stanghellini. 2003. Modelling salt accumulation in a closed system: A tool for management with irrigation water with poor quality. Acta Hort. 641:143-146.

Kiehl, P.A., J.H. Lieth, and D.W. Burger. 1992. Growth response of chrysanthemum to various container medium moisture tension levels. J. Amer. Soc. Hort. Sci. 117:224-229.
Levander, O.A. 1990. Fruit and vegetable contributions to dietary mineral intake in human health and disease. HortScience 25:1486-1488.

Maruo, T., H. Hoshi, M. Hohjo, Y. Shinohara, and T. Ito. 2001. Quantitative nutrient management at low concentration condition in NFT spinach culture. Acta Hort. 548:133-140.

Massa, D., N.S. Mattson, and H. Lieth. 2008. An empirical model to simulate sodium absorption in roses growing in a hydroponic system. Sci. Hort. 118:228-235.

Matysiak, B. and M. Bielenin. 2005. Nutrient solution composition on growth, flowering, nutrient status and cold hardiness of Rhododendron yakushimanum grown on ebb-andflow benches. Europ. J. Hort. Sci. 70:35-42.

Molitor, H.D. 1990. The European perspective with emphasis on subirrigation and recirculation of water and nutrients. Acta Hort 272:165-173.

Morvant, J.K., J.M. Dole, and A. Allen. 1997. Irrigation systems alter distribution of roots, soluble salts, nitrogen and $\mathrm{pH}$ in the root medium. HortTechnology 7:156-160.

Norrie, J., M.E.D. Graham, and A. Gosselin. 1994. Potential evapotranspiration as a means of predicting irrigation timing in greenhouse tomatoes grown in peat bags. J. Amer. Soc. Hort. Sci. 119:163-168.

Purvis, P., C. Chong, and G.P. Lumis. 2000. Recirculation of nutrients in container nursery production. Can. J. Plant Sci. 80:39-45.

Reed, D.W. 1996. Closed production systems for containerized crops, p. 221-245. In: D.W. Reed (ed.). Water, media and nutrition for greenhouse crops. Ball Publishing, Inc., Batavia, IL.

Rouphael, Y., M. Cardarelli, E. Rea, A. Battistelli, and G. Colla. 2006. Comparison of the subirrigation and drip-irrigation systems for greenhouse zucchini squash production using saline and non-saline nutrient solutions. Agr. Water Mgt. 82:99-117.

Rouphael, Y., M. Cardarelli, E. Rea, and G. Colla. 2008. The influence of irrigation system and nutrient solution concentration on potted geranium production under various conditions of radiation and temperature. Sci. Hort. 118: 328-337.

Rouphael, Y. and G. Colla. 2004. Modelling the transpiration of a greenhouse zucchini crop grown under a Mediterranean climate using the Penman-Monteith and its simplified version. Aust. J. Agr. Res. 55:931-937.
Rouphael, Y. and G. Colla. 2005. Growth, yield, fruit quality and nutrient uptake of hydroponically cultivated zucchini squash as affected by irrigation systems and growing seasons. Sci. Hort. 105:177-195.

Rouphael, Y., G. Colla, A. Battistelli, S. Moscatello, S. Proietti, and E. Rea. 2004. Yield, water requirement, nutrient uptake and fruit quality of zucchini squash grown in soil and soilless culture. J. Hort. Sci. Biotechnol. 79: 423-430.

Santamaria, P., G. Campanile, A. Parente, and A. Elia. 2003. Subirrigation vs drip-irrigation: Effects on yield and quality of soilless grown cherry tomato. J. Hort. Sci. Biotechnol. 78: 290-296.

Savvas, D., G. Meletiou, S. Margariti, I. Tsirogiannis, and A. Kotsiras. 2005. Modeling the relationship between water uptake by cucumber and $\mathrm{NaCl}$ accumulation in a closed hydroponic system. HortScience 40:802-807.

Schröder, F.G. and J.H. Lieth. 2002. Irrigation control in hydroponics, p. 265-298. In: D. Savvas and H.C. Passam (eds.). Hydroponic production of vegetables and ornamentals. Embryo Publications, Athens, Greece.

Siddiqi, M.Y., H.J. Kronzucker, D.T. Britto, and A.D.M. Glass. 1998. Growth of a tomato crop at reduced nutrient concentrations as a strategy to limit eutrophication. J. Plant Nutr. 21:18791895.

Uva, W.L., T.C. Weiler, and R.A. Milligan. 1998. A survey on the planning and adoption of zero runoff subirrigation systems in greenhouse operations. HortScience 33:193-196.

Uva, W.L., T.C. Weiler, and R.A. Milligan. 2001. Economic analysis of adopting zero runoff subirrigation systems in greenhouse operations in the northeast and north central United States. HortScience 36:167-173.

Van Os, E.A. 1999. Closed soilless growing systems: A sustainable solution for Dutch greenhouse horticulture. Water Sci. Technol. 39:105-112.

Von Post, L. 1922. Sveriges geologiska undersöknings torvinventering och några av dess hittills vunna resultat (in Swedish). Svenska Mosskulturföreningens Tidskrift 1:1-27.

Zheng, Y., T. Graham, S. Richard, and M. Dixon. 2004. Potted gerbera production in a subirrigation system using low-concentration nutrient solutions. HortScience 39:12831286. 